Mavi Atlas, 8(2)2020: 473-489

Makale Geliș | Received: 29.07.2020.

Araştırma Makalesi | Research Article

Makale Kabul | Accepted: 19.10.2020.

DOI: 10.18795 /gumusmaviatlas. 775468

\title{
Zülfikar ÖZKAN
}

Dr. Öğr. Üyesi

Üsküdar Üniversitesi, İnsan ve Toplum Bilimleri Fakültesi, Sosyoloji Bölümü, İstanbul- TÜRKİYE

Üsküdar University, Faculty of Humanities and Social Sciences, Depertman of Sociology, İstanbul-TURKEY

ORCID:0000-0001-9506-6528

Zulfikar.ozkan@uskudar.edu.tr

\section{Sağlığın Sosyolojik Boyutu}

\section{Öz}

$\mathrm{Bu}$ araştırmanın amacı, sosyal ilişkilerin ve sosyal bağların sağlık üzerindeki etkisinin ne olduğunu ortaya koymaktır. Bu çalışmada, sosyal bağlar konusunda gerçekçi bir bakış açısı ve farkındalık yakalayıp sosyal ilişkilerin iyileşmesi için öneriler sunulmaya çalışılmaktadır. Araştırmada veri kaynağı olarak kaynak taraması ve internet kullanılmıştır. Ayrıca basit yoğun gözlem yöntemi uygulanmıştır. Hastaların içinde yer aldığ1 olgular gözlemlenerek veri toplanmış ve değerlendirilmiştir. Sağlık personeli ve hastalar araştırmacının kimliğini bilmediklerinden, tutum ve davranışlarında değişiklik olmamıştır. Böylece her şey doğal akışı içerisinde incelenmiştir. Basit gözlem yolu ile elde edilen veriler, kaynak taraması yöntemiyle elde edilen bulgularla karşılaştırılmıştır. Elde edilen verilerin birbirlerini desteklediŏi görülmüştür. Çalışmaya temel teşkil eden ana veriler, Amerikada, İtalyan göçmenlerin yaşadığı bir yerleşke olan Rosetoda yaşayan köylüler ile bir Japon adası olan Okinowalıların yaşam şekilleri üzerinde gerçekleştirilen sosyolojik çalışmalardan alınmıştır. Bu çalışmalardan ve diğer bilimsel kaynaklardan elde edilen veriler incelenerek, sağlık ile sosyal ilişkiler arasında nedensellik ilişkisi kurulmaya çalışılmıştır. Rosetoluların ve Okinowalıların yaşam şekilleri, fiziksel etkinlikleri, genleri sosyal, kültürel ilişkileri ve ruh dünyaları ile sağlıkları arasında ilişkinin olup olmadığı hususu Oklahoma Üniversitesinden Prof. Dr. Stewart Wolf ve diğer araştırmacı bilim adamları tarafindan araştırılmış ve sonuçlar makalede bahsedilen eserlerle sunulmuştur. Başvurulan bütün kaynaklar, toplumdan tecrit olmanın ve izole bir hayat yaşamanın sağlı üzerinde olumsuz etkisi olduğunu göstermektedir. Bununla birlikte gereksiz tartışmalar ve kötü ilişkiler sağlığa zarar vermektedir. Araştırma sonucunda elde edilen bulgular, sosyal bağların ve sosyal ilişkilerin sağlık üzerinde anlamlı bir ilişkisinin olduğunu göstermektedir.

Anahtar Kelimeler: Mutluluk, Sosyal ilişkiler, Sağlık, Sosyalleşme, Duygusal Yıkım, Mutluluk Hormonları

\section{Sociological Dimension of Health}

\begin{abstract}
The purpose of this study is to present the impact of social relations and social bonds on happiness. In this study, it is aimed to develop a realistic view and an awareness and to provide suggestions for the betterment of social relations. Data that has formed the basis of this study is obtained from sociological research conducted on the lifestyles of the people of the Japanese island of Okinawa, and of the Italian migrants in the Roseto village of the USA. It has been aimed to establish a causal relationship between happiness and social relations by analysing the data from those research and other scientific sources. Scientists have collected information about lifestyles, physical activities, genetics, social and cultural relations, and psychologies of Roseto and Okinawa people. All resources show that exclusion from society and living in isolation have a negative impact on health and happiness. Unnecessary quarrels and bad relationships are harmful to health. Good social relations have a vitamin effect, whereas bad ones make a poison effect. Three scientific research book tackling the subjects mentioned above are based in this study, and literature review method was used. From this aspect, the study can be considered as meta-analysis. The results obtained from the research indicate that the impact of social bonds and social relations on happiness is very important. The findings of this research show that there is a significant relationship between social relations and happiness. In addition to that, happiness created by social relations transmits from one person to another.
\end{abstract}

Keywords: Happiness, Social Relations, Health, Socialization, Emotional Destruction, Happiness Hormones 


\section{Giriş}

Mutluluk ile sağlık arasındaki ilişki son yıllarda ele alınmaya başlamış olsa da bu ilişki, insanlı̆̆ın başlangıcına kadar götürülebilir. Hemen hemen bütün canlılar doğduktan çok kısa bir müddet sonra kendi başlarının çaresine bakabilirken, insanoğlu hayatının başlangıcından sonraki en az 5-6 yıllık dönemde herhangi bir destek ve yardım almadan hayatını sürdüremiyor. Bu sebeple sosyal yardım, sosyalleşme, sosyal ilişkiler, sosyal destek büyük önem arz etmektedir.

Günümüzde çoğu insan samimi ilişkiler ve sosyal destek beklemektedir. Ancak insanların büyük çoğunluğu aradığı sosyal desteği bulamamaktadır. Kişinin bu ihtiyaçlarının karşılanmasının sağlığa ve mutluluğa katkıda bulunacağı pek çok bilimsel çalışma tarafından ortaya konulmuştur. Sosyal olmak, topluma ait olmak, topluma bağlı olmak, toplumla ilgili olmak, toplumun sorunlarını çözmeye açı olmak ve kendini toplumla ilgili işlere verebilmektir. İnsan sosyal bir varlık olduğu için, sosyal olmaktan uzaklaşması derin acılara sebep olmaktadır. Martin Heidegger diyor ki: "Sizi siz yapan şey büyük oranda çevrenizdeki dünyadır.” Bu sebeple beynimizdeki nöral bağlantıların sayısını artırmak için daha sosyal olmalıyız. Kaslarımız gibi, beynimiz de kullan-kazan prensibine göre çalışır.

Beden ile akıl karşılıklı olarak birbirlerini etkilemektedirler. Zihinsel faaliyetler ve sosyalleşme bedeni etkilemektedir. Bunun tersi de geçerlidir. Bedeni olumsuz olarak etkileyen faktörler, akıl sağlığını da etkilemektedir. İnsan, her zaman diğer insanlara muhtaçtır. Amerikalı Psikiyatrist Irvin Yalom bu konuda "Hiç kimse insanlarla ilişki ihtiyacını aşamaz", demiştir.

Dünya Sağlık Örgütü’ne göre, “Sağlık, yalnızca hasta veya sakat olmamak değil, bedenen, ruhen ve sosyal yönlerden tam bir iyilik halidir.” Kişinin tam sağlıklı ve mutlu olabilmesi, sosyal ilişkilerinin iyi olmasına bağlıdır. Sağlık tanımında geçen "sosyal yönlerden iyilik hali” bu çalışmanın ana konusunu teşkil etmektedir.

Sağlık ve mutluluk konusunda yapılan çalışmalarda, "Sosyal yönlerden iyilik haline" gerekli önemin verilmediği bir gerçektir. Bu sebeple ruh sağlığı alanında yapılan çalışmalar eksik kalmakta ve ruhsal sorunlar gün geçtikte artmaktadır. Bu çalışma mutluluk ve sosyal iyilik konularının önemine dikkat çekmek amacındadır.

Mutluluk, keyifli ve anlamlı yaşamaktır. Ed Diener'e göre, "Mutluluk, olumlu duyguların sık yaşanması, olumsuz duyguların daha az yaşanması ve yaşamdan yüksek doyum alınmasıdır" (Doğan, 2018: 457). Mutlu insanlar, sosyal ilişkilerinde daha iyi, arkadaşları daha çok, sosyal destekleri daha yüksek, evlilikleri daha sağlıklı ve diğer insanlara karşı yardımsever kişilerdir. Kendisi ve çevresiyle barışık olan kişi ruhsal bakımdan sağlıklıdır.

Sosyal iyilik, kişinin, insanlarla iyi geçinmesi ve başkalarına anlayışlı yaklaşabilmesidir. Sağlıklı insan, çevresindeki tüm canlılarla iyi ilişkiler içinde olur (İlhan, 2020). .

Öte yandan sağlı̆̆ın sosyal boyutu vardır. Dr. Bernie Siegel, kendileriyle ve yakın çevreleriyle barış içinde yaşayan insanların, diğer insanlardan çok daha az hastalandıklarını belirtmiştir. Bu sebeple sağlığı ve mutluluğu incelerken sosyal ortamı göz önünde tutmak gerekir.

Sosyal ilişkilerin önemi hakkında gerçekçi bir değerlendirme yapmaya ve öneriler ortaya koymaya çalışan bu çalışmanın önemli bir eksikliği tamamlamada katkı sağlaması beklenmektedir. Aynı zamanda bu çalışma, "mutluluk" ve "sosyal yönlerden iyilik" konularına dikkat çekmesi, bu alanda farkındalığın artırılması ve eğitim kurumları tarafından dikkate alınmasının gerekli olduğunu ortaya koyması yönünden önem taşımaktadır.

Sosyal ilişki, birbirlerinden haberi olan, en az iki insan arasında bir süre devam eden, anlaml,, belirli amaçları bulunan sosyal bağdır.

Tip ve sosyal hizmet gibi yardım amaçlı mesleklerin temelinde yatan itici güç, ilgidir. Müşfik bir cerrah sonunda kesip biçmek, şefkatli bir hemşire de acı veren işlemleri yapmak zorundadır. Ama neşter de iğne de nezaket ve şefkatin eşliğinde daha az acı verir. Fark edilmek, hissedilmek ve 
önemsenmek, acıyı anlamlı ölçüde hafifletir. Endişe ve terslenmek ise güçlendirir (Goleman,2007: 124, 312).

Kendimize odaklandığımızda, sorunlarımız ve zihnimizi meşgul eden şeyler hızla büyürken dünyamız daralır. Başkalarına odaklandığımızda ise sorunlarımız zihnimizin odağından çıkar ve daha küçük görünürler.

Bu çalışmanın amacı, her alanda, sosyal ilişkilerin mutluluğa katkısının ne olduğunu ortaya koymak ve bulgular ışığında gelecekte gerçekleşebilecek çalışmalara yönelik öneriler geliştirmektir.

Yöntem

$\mathrm{Bu}$ araştırma, literatür taramasına dayanılarak yapılmıştır. Araştırmada sosyal ilişkilerin sağlıkla ilişkisi konusunda en çok atıf yapılan, Malcolm Gladwell, Stefan Klein, Barbar Nigel ve Anne Defaur'un adı geçen eserleri incelenmiş, ilgili diğer kaynaklar taranmış ve kendi araştırmalarımızla ilişkilendirilerek analiz yapılmıştır.

Bilimsel araştırmalar amaçlarına göre iki kısma ayrılır: Temel araştırmalar ve Uygulamalı araştırmalar.

Temel araştırmalar, olaylar arasındaki ilişkileri bulmak ve teori geliştirmek için yapılır. $\mathrm{Bu}$ araştırmaların amacı bilime katkıda bulunmaktır.

Uygulamalı araştırmalar ise, günlük pratik sorunlara çözüm ararlar. Belli konularda kamuoyunu aydınlatmak, ekonomik, sosyal, sağlık gibi konularda tahminlerde bulunmak gibi amaçlara hizmet ederler. Bu araştırmaların asıl amacı güncel hayatın gerçek bir sorununa cevap arama yönündedir (Seyitoğlu, 2003: 20).

Bu çalışmada, sosyal ilişkilerin sağlık üzerindeki etkisinin ne olduğunu araştırmak amacıyla daha önce yapılan araştırmalardan çok önemlileri incelenmiş ve bir sonucu varılmıştır.

$\mathrm{Bu}$ araştırmanın odağında bulunan, Gladwell, Barbar Nigel ve Klein, Amerika'da İtalyalıların yerleşme yeri olan Roseto köylülerinin, Defour'da bir Japon adası olan Okinowa'lıların, yaşam şekillerini, fiziksel etkinliklerini, genler sosyal ve kültürel ilişkilerini ve ruh dünyalarına ait bilgileri toplanmış, incelenmiş ve bunları sağlıklı kılan faktörlerin neler olduğunu ortaya koymuşlardır.

Literatür taraması yapılarak ve daha önce hastane ortamında elde edilen bilgiler taranarak sonuçlara ulaşılmıştır. Bu konuda pek çok sağlık personeli ile görüşmeler yapılmış ve onların uygulamalarından faydalanılmıştır.

İtalyalı Roseta köylülerinin mutluluk sırrı klasik olmuştur. Roseto Valfortore, Roma'nın yüz mil güneydoğusundaki olan bir taşra kentidir. Amerika'daki İtalyan göçmenlerin yaşadığı bir şehre Amerika'da Roseto adı verilmiştir. Bu kentin adı daha çok 1961 yılında, kasaba doktorunun, Oklahoma Üniversitesinden Prof. Dr. Stewart Wolfla yaptığ1 sohbet sırasında duyulmuştur. Bu doktor, kasabada yüksek risk grubu olan 55 ile 64 yaş arasındaki insanların kalp krizi geçirmediğini, 65 yaş üstündeyse kalp krizine bağlı ölüm oranının yalnızca \%1 olduğunu Dr. Wolf a anlatmıştı. Bu görüşmeler Dr. Wolfu düşündürmüştü. Çünkü sağlık konusunda, Roseto, A.B.D. ortalamalarından çok daha iyi bir durumdayd.

Roma'nın yaklaşık yüz altmış kilometre güneydoğusundaki Roseto Valfortore şehrinden Amerika kıtasına on dokuzuncu yüzyılda giden İtalyan göçmenler Pensilvanya'ya gelerek yine Roseto adında bir kasaba kurdular. Bu kasabanın halkı okuma-yazma bilmiyordu ve fakirdi. Rosetolular geçimini sağlayabilmek için ağır işlerde çok fazla çalışıyordu. Halk yıllardır mermer ocaklarında veya kasabalarından çok uzaktaki vadide ziraatla iştigal ediyordu. Bununla birlikte, kasaba halkının gelir dağılımı da bozuk değildi. Halk, paylaşımcı ve birlik beraberlik içindeydi. Ac1 ve tatlı günlerini paylaşmasını biliyorlardı. Yaşlıların itibarı yüksekti. Birbirlerine olan güvenleri çok fazlaydı. Buna bağlı olarak stres düzeyleri düşüktü. Sofralar hem mideleri hem de ruhları doyuruyordu. Oklahoma 
Üniversitesi'nde çalısan ve yaz aylarını Roseto yakınlarında geçiren Dr. Stewart Wolf Rosetoluların diğer Amerikalılara nazaran çok daha geç yaşlara kadar kalp rahatsızlığ çekmeden yaşadıklarını bölgede çalışan bir doktordan öğrendi. Bu duruma şaşıran Dr. Wolf, kasabada halkın kalp sağlığıyla ilgili araştırmalar yapmaya başladı. Çünkü kalp hastalıkları Amerika'da yaygındı ve 65 yaşından genç pek çok erkek kalp hastalığından ölüyordu. Oklahoma'daki meslektaşları ve öğrencilerinin yardımıyla Dr. Wolf Rosetoluların ölüm raporlarını inceledi. Gerçekten de kasabada 55 yaşın altındaki kişiler arasında kalp krizinden yaşamını yitiren veya herhangi bir kalp rahatsızlığı belirtisi olan kimse yoktu. Roseto'da 65 yaşın üstünde olan erkekler arasında kalp hastalığından ölenlerin oranı Amerika'dakinin yarısı kadardı. Wolf un incelemelerine göre, kasaba halkı arasında intihar vakası da yoktu. Kasabada suç oranı oldukça düşüktü. Burada hiç kimse sosyal yardım almıyordu ve ülser gibi hastalıklardan da mustarip değildi. Bu insanların en önemli ölüm nedeni yaşl1lık olarak görülmekteydi. Ayrıca Rosetolular sağlıklı beslenme alışkanlıklarına da sahip değildiler. Yemeklerini zeytinyağı yerine İtalya'da alışmış oldukları gibi domuz yağıyla pişiriyorlardı. Örneğin, yedikleri pizzanın muhtevasında domates, balık, soğan ve bol sıvı yağ vardı. Kasaba halkı spor yapmıyordu ve çok sigara içiyordu, birçoğu da kilo problemi yaşamaktayd1 (Gladwell, 2018: 10-13).

Rosetoluların sağlıklı oluş sebepleri, genetik faktörlerle açıklanabilir mi? "Wolf, bunun için Roseto'luların, ABD'nin başka yerlerinde yaşayan akrabalarını inceledi. $\mathrm{Bu}$ da değildi... Pennsylvania'da dağ eteklerindeki temiz havada yaşamak etkili olabilir miydi? Roseto'ya en yakın iki kasaba, dağın hemen aşağısında bulunan Bangor ile birkaç kilometre uzaklıktaki Nazareth idi. Her ikisi de Roseto ile yaklaşık aynı büyüklükteydi ve her ikisinin de nüfusu aynı türden, yani çalışkan Avrupalı göçmenlerden oluşuyordu. Wolf, her iki kasabanın da tıbbi kayıtlarını taradı. Nazareth ve Bangor'da 65 yaş üzeri erkeklerde kalp hastalığından ölüm oranı, Roseto'dakinin üç katı olarak görünmekteydi (Gladwell, 2018: 13).

Roseto sıradan bir Amerikan kasabasına benzediği zaman, hastalık ve ölüm oranları da kısa sürede A.B.D ortalamasını yakalamıştı. İnsanlar arasındaki sosyal ilişkiler, sosyal bağlar zayıfladıkça sağliklar da bozuluyordu.

Gerçekten fazla maddi imkânlara sahip olmamak insanları mutsuz etmiyor. İnsanları, başkalarından az ekonomik güce sahip olmak mutsuz ediyor. Çünkü kişi maddi imkânlarının azlığ1 sebebiyle kendini değersiz hissediyor. Roseto'daki insanlar, başkalarını kendilerinden zengin görüp üzüntüye kapılmamışlardı. Mal varlığını göstertmek Roseto’da iyi karşılanmazdı. Anne- babalar, ailelerinin yaşlı mensuplarıyla ve çocuklarıyla üç nesil aynı çatının altında yaşamanın keyfini çıkarıyorlardı. Bir toplumda insanların güçlü ilişkiler kurması için hayat tarzlarının birbirine benzemesi gerekir. Zitlıklar büyürse, toplumsal bağlar çözülür ve insanlar farklı dünyalarda yaşamaya başlar (Klein, 2004: 254-255). Bu durumda insanlar birbirinden uzaklaşır ve mutsuzluk giderek artar. Roseto'nun sırrı, diyet, egzersiz, genetik faktörler ve yaşadıkları yer değildi.

\section{Sosyal İlişkiler}

Dr. Wolf un incelemelerine göre, Rosetolular birbirlerinin evlerine gidip geliyordu, dışarıda karşılaştıklarında birbirleriyle uzun uzun hasbihal ediyorlar, evlerinin bahçelerinde açık havada bir arada yemek yemeyi seviyorlardı. Evlerde büyük annelerle büyük babalar büyük sayg1 görüyorlardı. Zenginler, kendilerini beğenip, diğerleriyle görüşmeme gibi bir davranıştan çok uzaktı. Aksine ihtiyac1 olanlara ellerinden geldiğince yardımcı oluyorlardı. Başarısızlıklar hemen kapatılmaya çalışılıyordu (Gladwell, 2018: 11).

Rosetoluları farklı kılan birbirlerine olan bağll1ıklarıydı. Bu kişiler Pensilvanya'ya küçük bir İtalya kasabasının tüm ananelerine sahip çıkmışlardı. Bu kasabada yoksullarla zenginler ayırt edilemiyordu. Kasabadaki kulüplerde beraber oyun oynuyorlar, akşam üzeri beraber yürüyüşe çıkıyorlar, dini günleri ve kilise şenliklerini beraber kutluyorlardı. 
Yılların geçmesiyle, Roseto'nun gençleri, yavaş yavaş kasabayı terk edip, büyük kentlere okumaya ve çalışmaya gidiyorlar... Çoğu iyi paralar kazanıp geri döndüklerinde, Roseto'nun merkezinin dışında, yüzme havuzlu, lüks evler inşa ediyorlar. Ancak artık üç nesil bir arada yaşamıyordu Çocuklara, engin yaşam denizinde fener olan yaşlılar yoktu. Ortak sofralar, ortak anlayış ve ortak ruhlar dağıliyordu.

Tüm bu mutlu günler, Roseto'nun da Amerika'nın diğer yerlerine benzemesiyle son bulmuştu. Nüfuz zenginleşmiş, fakat topluluk dağılmıștı. 1970'ten itibaren, gençler eğitim için kasabayı terk etti ve ailelerinin yaşadıklarından farklı anlayışla geri döndüler. Bazıları Kadillak marka arabayla geldiler. Büyük evler inşa edip etrafını çitle çevirdiler. Bahçelerine yüzme havuzları yaptılar. İnsanlar artık kendi dört duvarlarının arasına çekildiler. Refahın tadını çıkarmışlardı.

Araştırmalarında Dr. Wolfun farklı bulduğu en önemli şey, kasabalıların kurduğu çok güçlü sosyal bağlardı. Sosyal anlamda iyi bir temele sahip olan kişiler daha iyi ve daha uzun yaşıyor. Roseto'da gerçekleştirilen çok sayıda sosyolojik çalışma, kendini iyi hissetmenin, ömür beklentisini olumlu yönde etkilediğini ispat etmiştir (Klein, 2004: 256).

Rosetolular, sağlıklı yaşamın, sadece yediğimiz içtiğimizden ibaret olmadığını göstermesi sebebiyle çok önemlidir. Yılların geçmesiyle, kendi yaşama tarzlarından uzaklaşan Rosetoluların ortak sofraları yok olmuş ve artık ortak ruhları dağılmıştır. Rosetolular da şimdi, başkaları gibi yaşıyor ve onlar gibi ölüyor.

\section{Okinawalıların Yaşama Biçimi ve Mutluluk}

Okinawa'da yaşama biçimi ile mutluluk arasında bir ilişkinin olduğu çeşitli araştırmalarla ortaya çıkmıştır. Araştırmalara göre, Japon adası olan Okinawa'da 100 yaşını aşmış kişilerin, batı ülkelerine göre oranı yedi kat daha fazladır. Okinawalılar sağlıklıdır, çok az et yemeği yerler, yediklerinin dörtte üçü bitkisel besindir. Hareketli yaşama alışkanlıkları vardır. Sosyal ilişkilerini güçlendirerek stresi makul seviyelere çekerler. Bu ülkede yaşlı insanlar büyük saygı görür. Okinowa'da yüz yaşını geçmiş kimseler toplumun hazineleri olarak görülür. Dostluk ve komşuluk anlayışları gelişmiştir. Fazla öfkeye kapılmazlar. Dünyaya iyimser bir gözle bakarlar. Okinawalıların kin ve düşmanlık duyguları yok denecek kadar azdır. Kolay çözüm üretirler. Çünkü Herkes birbiriyle uyum içinde olduğundan, sorunlarını kolayca çözerler (Defaur, 2009: 65).

$\mathrm{Bu}$ çalışmalar Türkiye'de bazı bilim adamlarının da dikkatini çekmiştir. Türkiye' deki araştırmalarda benzer sonuçları vermektedir (Yllmaztürk, 2008:26). Okinawa halkı arzu edilen şekilde sosyalleşmiştir. Halk, beraberce kahvaltıya gider ve akşamları müzik dinler. Tüm bu yörelerde insanların genç ve sağlıklı kalmasının sebebinin genlerden çok yaşama biçimine bağlı olduğu anlaşılmışır.

Okinowada dikkat çeken nokta ise yemek ve genlerde değil, yaşama biçimi. Okinowalıların sırdaşları, her şeyi paylaşabilecekleri dostları var. Dost sahibi olmak Okinavalılar için bir zorunluluk gibidir. Çünkü her birinin sırdaş, her şeyi paylaşabileceği altı dostu var. Her zaman, her durumda birbirinin yanında oluyorlar. Okinowaların mutlu oluşlarının temel sebebi genleri kadar gündelik yaşama tarzları ve sosyal ilişkileridir.

\section{Sosyalleşme}

Sosyalleşme bireyin, biyolojik bir yapıdan sosyal bir varlık hâline gelme sürecidir. Sosyalleşmenin, büyüme, olgunlaşma, gelişme dönemleri vardır. Kişinin sosyalleşmesi için içinde bulunduğu toplumun sosyal, kültürel normlarını ve değerlerini benimsemeli ve kişiliğine yansıtmadır. Genç olsun yaşlı olsun her insan mensubu bulunduğu grubun, birlik, işleyiş ve devamını tehdit eden davranışlarda bulunduğu zaman toplumun tepkisiyle karşılaşır. Toplum, kendi değer ve normlarına ters düşen bu fertlere karşı gereken tedbirleri alır. Sağlıklı toplumlarda, sosyalleşme mutluluğu hizmet 
eder. Sosyalleşme bütün fertleri birbirine bağlayarak mutluluğun yaşanmasına yardımcı olur (Aslantürk ve Amman, 1999: 187).

Sosyalleşme, toplum içinde farklı kuşakların birbirleriyle olan iletişimini ve etkileşimini sağlar. Sosyalleşme süreci, insanın sağlığı ile doğrudan ilişkilidir. Kişinin aldığ1 eğitimin, çevresinin, topluma uyumunun, kendisiyle barış içinde olmasının sağlığ1 üzerinde etkisi vardır. İyi sosyal ilişkilerin iyileştirici, kötü sosyal ilişkilerin zehirleyici etkisi vardır.

Her insan, önemli görevleri başarıyla tamamlamayı, kendileri için önemli insanların onayını, saygısını, sevgisini kazanmayı ister. Duygusal rahatsızlıkların birçoğu, insanların kendilerini küçümsemelerinden kaynaklanır. Kendini küçümseme, kayg1, depresyon ve değersizlik duygularına sebep olur (Özkan, 2017: 224).

\section{Şefkat Atmosferi}

Pek çok hastanenin sunduğu teknolojik mucize, hastalara, şefkat atmosferi kadar yardımc1 olamıyor. Hastalar insani sıcaklıktan mahrum kalıyor. Sıcak bir gülümseme, uzanmış bir el, modern bilimin sunabileceklerinden çok daha değerli olabiliyor. Ancak bu ilgiye ulaşmak o kadar kolay olmuyor (Cousins, 2003: 141).

Yemekte ne yenildiğinden çok, yemeğin nasıl yenildiği önemlidir. Keyifli bir sofrada, neşeli ve şefkat dolu bir öğünün sağlığı, birçok vitamin karışımı ya da az pişmiş gıdadan daha olumlu etkilediğini birçok araştırma gözler önüne sermektedir. Keyifle yenen bir yemekte stres hormonlarının yoğunluğunun daha düşük olduğu ortaya çıkmıştır. Araştırmacılara göre, yemeğin günlük hayatın içinde önemli bir yer tuttuğu bölgelerde kalp ve dolaşım sistemi hastalıkları daha az görülmektedir ( Werner, 2009: 43).

Pek çok hastanenin sunduğu teknolojik mucize, hastalara, şefkat atmosferi kadar yardımc1 olamıyor. Hastalar insani sıcaklıktan mahrum kalıyor. Sıcak bir gülümseme, uzanmış bir el, modern bilimin verdiğinden çok daha değerli olabiliyor. Ancak bu ilgiye ulaşmak o kadar kolay olmuyor. Mutluluk, arkadaşlık ve aile şefkati üzerinde yetişir. Şefkat, kişinin kendisi ve başkaları için sevgi duymasıdır. Şefkatli kişi, kendini de başkalarını kabul eder.

ABD'de birkaç yüz bin insan üzerinde yapılan çok sayıda araştırma sonucuna göre, sosyal temaslar hayat kalitesini ortalamada en az sigara içmek, yüksek tansiyon, aşırı kilolar ve düzenli yapılan spor kadar etkilemektedir. Yaştan, sağlık durumundan ve cinsiyetten bağımsız olarak yalnız bir insanın önümüzdeki yıl içinde ölme ihtimali, çevresi tanıdıklarla çevrili birinin iki katıdır. Buna karşın sigara bağımlılı̆̆ı, ölüm riskini sadece bir buçuk katı oranında artırır (Klein, 2004: 164).

Hastalıkları hakkında konuşabilen hastaların daha az acı çektiklerine biz de yaptığımız gözlemlerle tanık olmuş bulunuyoruz. İnsan sıcaklığı hastaların sağlıkları üzerinde etkili olabiliyor. Yalnızlık, ruha ve bedene yük olur. Sosyal destek stresle mücadelede en etkili bir yoldur. Duygusal bağlar tedavi edicidir.

\section{Mutlu Olmak Zorunda miyı?}

Kişi hem kendisi içi hem de içinde bulunduğu toplum için mutlu olmak zorundadır. İnsanın hayatının amacı ve anlamı tekâmül etmek ve mutlu olmaktır. "Mutluluk, kişisel sebeplerle değil toplumsal sebeplerle de ciddiye alınmalıdır. Birey öncelikle yakın çevresindeki kişiler olmak üzere, hayatına giren her kişi için mutlu olmalıdır. Her insan, eşi, çocukları, arkadaşları, işçileri yani hayatına giren her kişi için mutluluğu seçme ve mutluluğa karar verme mecburiyetindedir. Birey özellikle yakın çevresindekiler için mutluluk üzerinde çalışmalıdır (Dennis, 1998: 149).

"Mutlu olma ödevi kadar küçümsediğimiz başka hiçbir ödev yoktur. Oysa mutluyken dünyaya anonim mutluluk tohumları ekeriz" der Robert Louis Stevenson. Mutluluk öğrenilebilir. Yeter ki beynimizi kişi beynini akıllıca yönetebilsin... 
Epikuros diyor ki: “Akıllı, dürüst ve insaflı olmadan mutlu yaşanamayacağı gibi, mutlu olmadan da akıllı, dürüst ve insaflı olunamaz." Gerçekten toplumun akıllı, dürüst ve insaflı insanlara ihtiyac1 vardır. Insanlar mutlu olmadan da bu vasıflara ulaşamazlar. Birey mutlu olduğu zaman başkalarına daha olumlu duygularla yaklaşır ve onlarla olumlu ilişkiler içinde oluruz. İnsanlar mutlu olmak için başkalarının kalbine ve zihnine muhtaçtır. Mutluluğun genel geçer kuralları vardır. İnsanlar birbirine benzer. Mutluluk kurallarını izleyen herkes mutlu olabilir.

\section{Mutluluk ve Sağlik}

Kişinin kendi fark etmese bile beyin devreleri kararı doğrultusunda çalışmaya başlar. Modern bilim nasıl mutlu olunacağını gözler önüne sermiştir. Beyin araştırmacıları, iyi duyguları araştırıp onları ölçebilmenin yollarını bulmuşlardır.

Beyin, mutluluk kararı doğrultusunda, mutluluk hormonlarını olan, serotonin, endorfin, dopamin, oksitosini harekete geçirir. Beyin, mutluluk kimyasallarını, hayatta kalmaya ve mutlu olmaya karar verdiği zaman salg1lar. Mutlu olmaya karar veren kişinin beyni, ona doğru yolu gösterir.

Toplumsal yapının sağlam olduğu, yerlerde insanlar daha mutlu yaşar. Bir toplumda insanların birbirine güveni ne kadar fazlaysa, adalet anlayışına kadar güçlüyse ve vatandaşlık bilinci ne kadar yüksekse, o toplumun mutluluk oranı o kadar büyük olur.

Bunun aksine toplumdaki karşıtlıklar artarsa herkes sağlığını ve mutluluğunu yitirir. Zengin yoksul fark etmez. Mutluluk, kişinin iyi olma ve içinde bulunduğu durumdan hoşnut olma hâlidir.

Sonja Lyubomirsky’nin belerttiği gibi(Lyubomirsky, 2008), mutlu olmak belli düzeyde kişinin elindedir, belli düzeyde de genetik faktörlere ve yaşam şartlarına bağlıdır. Lyubomirsky mutluluğun belirleyicilerini 3 grupta ele almaktadır :

$\% 50$ oraninda genetik faktörler.

$\% 10$ yaşam şartları.

\% 40 Gönüllü faaliyetler (Amaçlı etkinlikler)

Mutluluğumuzun genlerle belirlenen kısmı için yapılabilecek bir şey yok, yaşam şartlarını da belirlemek zordur. Ancak geriye kalan \% 40 tamamen kişinin kontrolündedir. Bu \% 40' lik oran bireyin nasıl düşündüğüne ve ne yaptığına bağlıdır. Lyubomirsky araştırmaları, mutluluğun her insanın elinde olan \%40'lık bölümünü pozitif olarak yükseltmek ve daha mutlu bir insan olmak için 12 maddelik bir "yapılacaklar listesi" öneriyor. Bu liste özet olarak şöyledir:

Şükretmek,

Pozitif olmak,

Fazla düşünmekten ve sosyal karşılaştırmalar yapmaktan kaçınmak,

İyilik yapmak, nezaket içeren davranışları arttırmak,

Sosyal ilişkilerimizi beslemek ve zenginleştirmek,

Zorluklarla başa çıkma stratejileri geliştirmek,

Affetmeyi öğrenmek,

Akışı arttıran deneyimler edinmek,

Mutluluk ve sevinçlerin tadını çıkarmak,

Manevi değerlere önem vermek

Hedef belirlemek

Bedeni sağlıklı hale getirmek 
Her insanın farklı olması nedeni ile her birimizde fayda yaratacak ve öne çıkacak tavsiyeler de farklı olur. İyilik yapmak ve sosyal ilişkiler kurmak başlıklı mutluluk etkinlikleri konumuzla ilgili olan kısımdır. "Sosyal ilişkilerimizi beslemek ve zenginleştirme" mutluluğun temel belirleyicilerinden birisi olduğu gibi sağlıklı olmayı da büyük oranda etkilemektedir.

\section{İyilik Yapmak}

İyilik yapmak, sadece bundan yararlanana değil, iyiliği yapana da faydalıdır. İyiliğin olmadığ1 yerde mutluluk olmaz diyor Thamas Carlyle. İyilik, kişinin hayatına anlam ve değer katar. Başkalarına yardım eden kendini değerli hisseder ve şükretmesine sebep olur. İyilik yapan, çevresinden minnet ve takdir toplar. Başkalarının saygısını kazanan kişinin beyni serotonin salgılar. Ancak yardım istemeyen birine zorla yardım etmek mümkün değildir.

\section{Sağlıklı Sosyal İlişkiler Kurmak}

Sağlıklı sosyal ilişkiler kurmak için, vakit ayırmak, hayranlık, takdir ve şefkat göstermek, güzel olaylara sevinmek, çatışmalarla başa çıkmak, iç dünyayı paylaşmak ve insanların birbirinin ilgilerine sayg1 göstermeleri gerekir.

İnsan gönül almasını da bilmeli. Örneğin, mutlu evliliklerde pozitif ve negatif ifadeler beşe bir oranındadır. Bu ilişkilerde, her negatif yoruma (eleştiri, dırdır, azarlama) karşılık beş pozitif yorum yer alıyor. Bu kuralın bilincinde olan kimse her alanda sosyal ilişkilerini zenginleştirebilir. John Donne' in ifadesiyle "Hiç kimse tek başına bir ada değildir." Bu sebeple kişi içinde bulunduğu toplumla bütünleșebilmelidir.

Yapılan araştırmalara göre, haksız yere eleştirildiklerini düşünen işçilerin koroner kalp hastalığına yakalanma oranı, adil muamele gördügünü düşünenlere oranla \% 30 daha fazladır. Bir araştırmada, yüz kadın ve erkeğin bedenlerine birisiyle etkileştikleri sırada tansiyonlarını ölçen bir alet yerleştirilmişti. Bu kişiler sevdikleri dostları veya aileleriyle birlikte oldukları zaman, tansiyonları düşüyordu. Çeşitli sorunlar yaşayan bir kimseyle beraber olduklarında, tansiyonları artıyordu. En büyük sıçrama ise karışık duygular besledikleri zorba bir anne-baba, sinirli bir sevgili, rekabetçi bir arkadaş gibi birisiyle beraberken meydana geliyordu (Goleman, 2007: 278-285).

\section{Aile Desteğinin Sağlık Üzerindeki Etkisi}

Zor durumlarda aileden ve sosyal çevreden görülen destek, stresin etkisini azaltıyor. Aile üyelerinin birbirlerine değer vermesi, aile ortamımı huzura kavuşturuyor. Aile desteği, kişilerin endişelerini azaltıyor, onların daha iyimser ve daha sağlıklı olmalarını sağlıyor. Aile ve sosyal bağları güçlü insanların ömrü uzun oluyor.

Aile desteği konusunda en önemli araştırmalardan birini John Gottman ve Nan Silver yapmışlardır. Gottman ve Silver, kısa bir müddet önce laboratuarlarında, iyi bir evliliğin, bedenin kendini hastalıklara karşı savunmasına öncülük eden bağışıklık sistemine doğrudan katkıda bulunarak, sağlığı koruyabileceğine ilişkin bazı ön deliller açığa çıkardı. Araştırmacılar yaklaşık on yıldır, boşanmanın bağışıklık sisteminin işlevini zayıflatacağını biliyorlardı. Sistemin yabancı istilacılarla savaşma yeteneğindeki bu düşüş, bedeni bulaşıcı hastalıklarla karşı kaşıya getirmiştir.

Gottman-Silver, şimdi bunun tam tersinin de doğru olabileceğini buldular. Mutlu çiftler, bağışıklık işlevindeki bu zayıflamadan kaçınmakla kalmıyor, ayrıca bağışıklık sistemleri fazladan bir destek de görebiliyor. Sevgi Laboratuvarında bir gece kalan 50 çiftin bağışıklık sistemi tepkilerini sınayan Gotman- Silver, evliliklerinden çok hoşnut olanlarla, birbirine nötr bir duygusal tepki veren ya da mutsuz olanlar arasında çarpıcı bir farklılık keşfetmişlerdir. Özgül olarak her denekten alınan kan örneklerini, bağışıklık sisteminin başlıca savunma silahları olan birtakım akyuvarların tepkisini sınamak için kullanılmışlardır. Genelde, yabancı istilacılara karşı koyan bu akyuvarlar, mutlu çiftlerde öteki deneklerdekine kıyasla daha fazla çoğalıyordu. Ayrıca diğer bağışıklık sistemi savaşçılarının, zarar görmüş veya değişikliğe uğramış örneğin iltihaplı veya kanserli beden hücrelerini yok eden tümör 
hücrelerinin büyümesini sınırladıkları bilinen doğal katil hücrelerin etkinliğini sınamışlardır. Gene, evliliklerinden hoşnut olan deneklerin doğal katil hücreleri, öteki deneklerinkine göre daha etkiliydi. Hepsi olmasa da çoğu büyük granüler lenfosit, çoğunlukla doğal öldürücü hücreler olarak bilinirler. Bağışıklık sitemindeki bu güçlenmenin, iyi bir evliliğin sağlığa katkıda bulunup ömrü uzatmasını sağlayan mekanizmalardan biri olduğunun ispat edilebilmesi için, daha fazla inceleme yapılması gerekir. Ancak en önemlisi iyi bir evliliğin bunu sağladığını kesinlikle bilmemizdir. Aslında, vücutlarının biçimini korumaya meraklı olanların haftalık sporlarının yalnızca $\% 10$ unu, örneğin günde 20 dakikalarını, bedenleri yerine evlilikleri üzerinde çalışarak geçirselerdi, sağlıkları açısından üç kat daha yararlı olurdu (Gotman- Silver, 2002: 10-11).

Sağlıklı aile ilişkilerinin, sağlı̆̆1 iyileştireceği gibi sağlıksız aile ilişkileri de sağllğ̆1 olumsuz yönde etkilemektedir. Ailede hangi davranışın iyi veya kötü olduğunu ise Tolstoy’un şu ifadesinden faydalanarak bulabiliriz. 'Yalnızca bir tek özellik davranışların iyi veya kötü olarak sınıflandırılmasını sağlar. Eğer dünyadaki sevgiyi artırıyorsa, iyidir. Eğer insanları birbirinden ayırıyor ve aralarında düşmanlık oluşmasına sebep oluyorsa, kötüdür."

\section{Bakış Açısının Gücü}

Kişinin bir olaya, bir konuya ve bir düşünceye hangi yönden baktığ1 ile mutluluğu arasında yakın bir ilişki vardır. Bakış açısının genişliği başka bir ifadeyle seçenekleri çokluğunun mutluluk üzerinde etkisi vardır. Mutlu insanlar her şeyin en iyisine sahip olanlar değil, sahip olduklarından en çok faydalananlardır. Kötü yetiştirilmiş hazır besinler, üreterek mutlu olmayı bilmezler, tüketerek mutlu olmak isterler. Yağma zenginleri de böyledir. Onların üretme kültürleri yoktur. İnsanlar başlarına gelen olayları seçemezler, ama tepkilerini seçebilirler (Tarhan, 2019:20).

Sorunların çokluğu, kişinin sorunlara bakış açısını daralmaktadır. Sorunlar baş gösterince kişinin tüm dikkati, bu sorunlar hakkında endişelenmeye yönelir. O zaman bu tür zorlukların sadece onun başına geldiğini düşünür. Bu durumda kişi, kendini yıpratma sürecine girer. Acıyla dolu olduğumuz zaman zihnimizi sakinleştirmek çok zordur. Bununla birlikte, kişi başkalarıyla kıyaslamalar yaparak durumu faklı açıdan görebilirse, sorun onu daha az tedirgin eder. Gözümüzü sadece belli bir olaya diken kimse, o olayın gittikçe daha büyük görünmesine sebep olur (Lama s.152). Bu sebeple sosyal sorunlara daha geniş açıdan bakmaya çalışmak gerekir. Sosyal bağlar güçlendirildiği zaman, bakış açısı genişler ve daha mutlu olmanın kapıları açılmış olur.

\section{Ruhun İhtiyacs}

Ruhun vazgeçilmez besin kaynağı, başkalarına yararlı olduğunu hissetmesidir. Ölüm korkusunun büyük bölümü, hayatın hiçbir anlam taşımamasıından, boşu boşuna yaşamış olmaktan, varlığının hiç kimse veya hiçbir şey açısından bir fark yaratmamış olmasından duyulan korkuyla bağlantılıdır (Schreiber, 2008:41). Carl G. Jung diyor ki: "Nevroz, anlamını bulamamış ruhun acı çekmesidir."

Anti kanser kitabında David Servan Schreiber şöyle bir vaka anlatmaktadır: "Günün birinde her yeri dövmelerle kaplı, alkolizm, uyuşturucu ve şiddetle dolu uzun bir geçmişi olan Joe adlı bir genç adamın başucuna çağrıldım. Beyin kanseri olduğu söylendiğinde dizginlerinden boşanmış ve her şeyi alt üst etmeye başlamıştı. Benimle oturmayı kabul ettiğinde yanına yaklaştım ve Size az önce verilen haberi duydum. Çok öfkeli olduğunuzu biliyorum. Bunun hayli ürkütücü olduğunu tahmin ediyorum" dedim. Çaresiz durumdaydı. Babası alkolikti. Hiç arkadaşı yoktu. "Yararlı olduğu sürece sizinle her hafta görüşeceğime söz verebilirim” dedim. Joe sakinleşti ve ölünceye kadar altı ay boyunca her hafta benimle görüşmeye geldi. Çok geçmeden, hayatında hiçbir şey yapmamış olmasının, ölümü onun için dayanılmaz hâle getirdiği açıklık kazandı. Kalan zamanında birileri için yararlı bir şey yapıp yapamayacağını sordum ona. Bu konuda hiç düşünmemişti. Bir süre kafa yorduktan sonra, "Yaşadığım mahallede bir kilise var, sanırım onlar için bir şeyler yapabilirim. Bir havalandırma sistemine ihtiyaçları var. Bunun nasıl yapılacağını biliyorum" dedi. Gidip rahiple konuşması için onu teşvik ettim. Rahip 
bu öneriye çok sevindi. Joe her sabah kalkıp kiliseye havalandırma sistemi kurmak için çatı katına çıkıyordu. Beynindeki tümör nedeniyle yoğunlaşmakta güçlük çekiyordu.... Hayatında ilk defa başkaları için gerçekten önemli olan bir şey yapıyordu. Farklı bir insan olmuştu ve bir daha asla öfke nöbetine kapılmadı. Aslında sert görünümünün altında kocaman bir yüreği vardı. Joe, bir gün isse gelmedi. Onkoloğu beni arayıp hastaneye kaldırıldığını ve sonunun yaklaştığını söyledi. Odasına çıktım ve vedalaşmak için yatağına oturdum ve Joe gözlerini açtı. Benimle konuşmaya çalıştı ama gücü yetmedi. Dermansız bir el hareketiyle yaklaşmamı işaret etti. Sağ kulağımı dudaklarına yaklaştırdım ve "Hayatımı kurtardığın için Tanrı sizi korusun," diye mırıldadığını duydum. Bu ders bana yeterince güven verdi. Bir şekilde, Joe da benim hayatımı kurtarmıştı.”(Schreiber, s. 41).

Bu çok önemli bir derstir. Ölümün eşiğindeyken bile, insan hayatına anlam katabilir ve hâlâ kendi hayatını kurtarabilir.

\section{Mutluluğun Kaynağı Nedir?}

Acaba son derece mutsuz, bahtsız, talihsiz insanların, mutlu insanlardan farkı nedir? Mutlu insanlar, daha mı dindar? Daha iyi durumda mı? Daha fazla paraya mı sahipler? Görünüşleri daha mı iyi? Başlarına daha iyi olaylar mı başlarına geliyor?

Pozitif psikolojinin öncülerinden Amerikan Psikoloji Derneği başkanı Martin Seligman TED deki konuşmasında bu soruların cevabını veriyor.

Seligman diyor ki: "Mutlu insanlar, daha çok dindar değiller, daha iyi durumda değiller, daha iyi görünüşlü değiller, başlarına daha iyi olaylar gelmiyor. Farklı oldukları tek bir şey var: Son derece sosyaller. Yalnız zaman geçirmiyorlar, her biri geniş bir arkadaş repertuvarına sahip, her birinin romantik bir ilişkisi var. Merak ya da öğrenme isteği gibi zihinsel özelliklerin mutlulukla fazla ilgisi yoktur. Mutluluğu sağlayan, iyilik yapmak, değer bilme ve sevgi gibi erdemlerdir."

Bronnie Ware'nin “Ölmek üzere olanların pişmanlık duyduğu beş şey” adlı kitabında ölüm döşeğindeki insanların en samimi ve gerçek pişmanlıkları dile getiriliyor. Kitapta yazar kişisel deneyimlerini ve içsel yolculuklarını anlatmıştır.

Ware, Avustralya da bir bankada çalışıyorken bir karar alır ve sahip olduğu her şeyi satar, işten ayrılarak atlar arabaya ve canı nereyi isterse seyahat eder. Ne iş bulursa onu yapar. Genelde hastabakıcıllk yapar. Kitap hastalarla geçen sohbetlerden oluşuyor. 2012).

Bu çalışmada, ölmek üzere olan insanların pişmanlık duyduğu şu beş şeyi bulmuştur: (Ware, olsaydi.

Keşke başkalarının benden bekledikleri yerine, kendi istediğim hayatı yaşayacak cesaretim

Keşke bu kadar çok çalışmasaydım.

Keşke duygularımı açılayacak cesaretim olsaydı.

Keşke arkadaşlarımla ilişkimi kesmeseydim.

Keşke daha mutlu olmama izin verseydim.

Gerçekten insan, yalnızlıktan ölebiliyor. Günümüzde pek çok kişi, bir kimsenin dokunuşuna muhtaç oluyor. Ölmek üzere olan hastaların en çok pişman oldukları beş şeyden birisi, arkadaşlarıyla bağlantılarını koparmalarıdır. Yalnızlık, kalpte insanı fiziksel olarak öldürebilecek bir boşluk bırakır. Katlanılmaz bir acısı vardır. Yalnızlık, kişinin yanında, onu kabullenecek ve anlayış gösterecek kimsenin olmamasıdır. Bir kimsenin yanında kaç kişinin olduğu önemli değildir. Önemli olan, onu anlayan ve olduğu gibi kabul eden kimselerin yanında olmasıdır. Her insan, onu anlayan ve kabul eden kişilere büyük ihtiyaç duyar (Ware, 2012: 215). Yalnız kalan kimse, onu anlayan arkadaşlarını özler, çünkü o arkadaşları onun acısını hafifletebilir. Yalnız insanlara ayıracağımız kısa zaman dilimleri onların hayatını 
büyük ölçüde değiştirebilir. Bu sebeplerle, dost ve arkadaşların bir araya gelip sosyal ilişkilerini güçlendirmeleri önemlidir.

\section{Duygusal Y1kımlar Öldürücü Zehirler Yaratır mı?}

İnci Özgür İlhan'ın "Ruh Sağlığının Sosyal Boyutu” çalışmasında ifadeettiği gibi (Illhan, 2020), duygusal ve sosyal yıkımlar güçlü ve öldürücü zehirler yaratır. Yoğun bir duygu ve kızgınlık içinde olan kişilerden alınan kan örnekleri kobaylara enjekte edildiğinde onları iki dakikadan daha az bir sürede öldürmüştür. Şüphesiz bu zehirler bizim bedenimizi de öfke anında tahrip etmektedir. Aklımızdaki her düşünce beden kimyamızı bir saniyeden kısa bir sürede etkilemektedir (Matthews, 1999: 27).

Korkunun, kızgınlığın, hayal kırıklığının ve sıkıntının ortaya çıkardığı zehirler, kobayları zehirlediği gibi insanları da zehirler. Aynı anda hem korku dolu, endişeli ve sıkıntılı, hem de sağlıklı olmak imkânsızdır. Mutluluk ile gerginlik bir arada olmuyor.

Hastalık, sıklıkla zaman içinde kendilerini beden yoluyla gösteren çözülmemiş iç çatışmaların bir sonucudur. Bazı insanlar için hastalık ilgi çekmenin tek yoludur. Birey hasta olduğu zaman, arkadaşlarının ve ailesinin büyük ilgisini görür. Bu durumda daha çok sevildiğini ve güven ortamında olduğunu hisseder. Sevilmediğini ve ihmal edildiğini hissettiği zaman hasta olma eğilimi de azalır. Sevildiğini ve güvende olduğunu hisseden insanların daha az hasta oldukları ve daha az kaza geçirdikleri bir gerçektir (Matthews, 1999: 28). Bu gerçekler insanların sağlıklı sosyal ilişkiler kurmaya ne kadar ihtiyaçları olduğunu göstermektedir.

\section{Faydalı İşlerle Gelen Mutluluk ve Sağlık}

Dünyada yalnız bir kişinin emeğiyle ortaya çıkmış bir eser bulmak pek zordur. Bir ressamın eserindeki güzellik ona aittir. Ama resimdeki boyaların altında yatan tuvali dokumuş olan ustalar, renk renk boyaları hazırlamış olan boyacılar, fırçaları imal etmiş olan işçiler vardır. Yani insanlar her alanda birbirine muhtaçtır. Her insan mutlu olmak için topluma faydalı bir iş yapmalıdır.

Boş insan mutlu ve sağlıklı olamaz. İkinci dünya harbinden önce Almanya'da işsizliğe bir çare bulmak için bir takım boş gezen adamları toplayıp onlara güya iş gördürüyormuş hissini vermek için delik fiçılarla su taşıtmışlardı. Sabahtan akşama kadar delik fiçıya su taşımış olan adam düşüncelerini şöyle dile getirmişti: "Hayatımda bundan daha büyük bir işkence tasavvur edemiyorum. Faydasız ve lüzumsuz bir insan hâline geldiğimi ilk defa o günlerde hissettim. Üç gün çalıştıktan sonra aç kalmayı göze alarak delik fiçıya su doldurmak teklifini katı surette reddettim.” (Rado, 1956: 83).

Kendinin işe yaramadığını hisseden kişi mutlu olamaz. Gerçekten "Doğanın herhangi bir yerinde bir şey yararsızlaştığında, orada körelme görülür. İnsan bedeni içinde aynı şey geçerlidir. Doğada yararsızlaşan bir şey hemen ölür. Doğada ve kendi içimizde yararsız olan bir şeye yer yoktur. Ancak ve ancak gelişime, ilerleyişe katkıda bulunan şeylerde mümkündür sağlıklı oluş. Hayatta kalabilmenin tek yolu ilerlemektir.” (Chopra, 1987: 145). Kişi faydalı işler yaptığı oranda mutluluğunu artırabilmektedir.

\section{Demokrasi ve Mutluluk}

Demokrasi, halkın egemenliğine dayanan bir yönetim şeklidir. Demokrasilerde kararlar ortak alınır. Herkes kanunlar karşısında eşittir. Demokrasinin temelinde hoşgörü vardır.

Demokrasi ile yönetilen toplumlarda kişi genel olarak içinde bulunduğu toplumun hayatını düzenleyen kurallara uyar. Kurallara uyulmadı̆̆1 zaman ailede, okulda, çevrede kısaca toplumda bir kargaşa hüküm sürer. Bu düzensizliğin sonucunda şüphesiz huzursuzluk ve mutsuzluk oluşur. Yapılan birçok araştırma demokrasinin mutluluk oluşturduğunu göstermektedir.

"Demokrasi mutlu kılar. İsviçre'de birbirlerinden farklı siyasi sistemler yan yana yaşamaktadır. Çünkü ülkenin önemli kararları başkent Bern de değil, 26 adet kantonda alınmakta. Kantonlar bunun için doğrudan demokrasinin aygitlarından faydalanıyor.... Insanlar yönetimi katılabildikleri oranda 
hayatlarından memnundurlar. ... Siyasi etkinlik, memnuniyeti hesap bakiyesinden daha çok etkiliyor ve demokrasi insanı mutlu kilıyor (Klein, 2004: 264).

Vatandaşlık duygusu, toplumsal eşitlik ve kendi yaşamı üzerinde söz hakkına sahip olma, toplum içinde kendini iyi hissetmenin sihirli üçgenini oluşturur. Bu üçgen bir toplumda güçlü olduğu oranda, insanlar hayatlarından o kadar memnun olurlar. Daha önce bahsedilen Rosoto'da dayanışma öylesine baskındı ki insanlar kaderin herhangi bir darbesinden korkmaları gerekmiyordu. Vatandaşlık duygusu, sorumluluk anlamına gelir. "Bir şey yapmamak ve çaresizlik hissi, mutluluğun en büyük düşmanıdır. Buna karşılık eylem, mutluluğun anahtarıdır. Bu her bir insanın kişisel mutluluğu, özellikle de tüm toplum için geçerlidir. Mutlu bir hayat kaderin yazg1sı değildir. Bunun için harekete geçmek gerekir." (Klein, 2004: 268).

\section{Tartışma}

Sosyal ilişkilerin sağlık üzerinde etkisinin ne olduğunun incelenmesi amacı ile yapılan bu çalışmada, sağlıklı sosyal ilişkilerin vitamin etkisi, kötü sosyal ilişkilerin ise zehir etkisi yaptığı ortaya çıkmıştır. İnsanların birbirlerine karşı tepkileri, kalplerinden bağışıklık sistemine kadar sağlıklı ilgili her şeyi etkilemektedir. Kaliteli sosyal ilişkiler ile sağlık arasında ilişki vardır.

Doküman analizi yöntemi ile elde edilen bulgular yapılan bu araştırmanın varsayımını doğrulamaktadır. Beklenilenlerden farklı bir bulguya ulaşılmamıştır. Bununla birlikte, bu konuda yapılacak araştırmalar nicel analiz yöntemi ile derinleştirilmelidir.

Bu çalışmanın bir amacı da gelecek araştırmacılar için farkındalık yaratmaktır. Bu çalışmada sağlığın tanımından yola çıkarak "sosyal iyilik hâli” üzerinde durulmuştur. Bununla birlikte, sosyal iyilik hâli ve sosyal desteği "kanıta dayalı tıp" ve "koruyucu hekimlik" açısından da tartışmak gerekir.

Kanıta dayalı tıp, bir hastanın tedavisi hakkında karar verirken var olan kanıtlanmış bilgilerin dikkatli, açık ve mantıklı bir şekilde kullanılmasıdır. Kanıta dayalı tıp (KDT), hastanın tıbbi bakımı için karar alma sürecinde işe yarar. Hastalıkla alakalı yayımlanmış güncel ve en iyi kanıtların kullanır. 1970'li yıllardan itibaren tıp dünyasında etkisi artan KDT, klinik kararları daha çok güncel araştırma bulgularına dayandırır. Yöntem olarak hekimin mesleki birikimini esas alır. KDT uygulamaları hasta yaşamının tedavisinde maliyetinin çoğu zaman göz ardı edilmesi ve dar bir hasta gurubu üzerinde yapılmış olması sebebiyle eleştirilmektedir (Babaoğlu vd, 2009).

Hastalıkla mücadelenin en etkin ve hesaplı yolu, hastalı̆ga yakalanmadan evvel koruyucu önlemler almaktır. Koruyucu hekimlik bu manada ortaya çıkabilecek hastalıklara önceden tıbbi müdahale ve telkin yollarının kullanılmasıdır. Tip dilinde hekimliğin yarısı koruyucu hekimlikle ilgili iken diğer yarısı, diğer yarısı tedavi hekimliği ile ilgilidir. Bunun için her doktorun hastasını iyi tanıması, tetkik ve yöntemlerle asıl sebebe ulaşması çok önemlidir.

Sosyal destek, "kanıta dayalı tıp" açısından yeteri kadar ilgi görememektedir.

Gürhan FIŞEK (2015). “Sosyal İyilik Hali”, adlı makalesinde hastalığın tıp biliminin konusuna girdiğinden bahisle doktorların üzerinde çalışması gerektiği ileri sürmemtedir. Ancak sağlık hem tıp bilimlerinin ve hem de sosyal bilimlerin konusudur. Çağdaş Sağlık anlayışının en geçerli tanımı, 1948'de imzalanan Dünya Sağlık Örgütü (WHO) Anayasasında vardır. Bu anayasadaki tanım 1961'de yayınlanan “Sağlık Hizmetlerinin Sosyalleştirilmesi Hakkında Kanun'da da yer almaktadır. "Sağlık, yalnızca hasta ve sakat olmamak değil, bedenen, ruhen ve sosyal yönlerden tam bir iyilik hâlidir" tarifinde üzerinde durulması gereken nokta, sağlıklı olmak için tek başına bedensel ve ruhsal iyilik halinin yetmemesidir. Sosyal iyilik de üzerinde de durulması gerekir.

Sağlıklı olmak, sosyal olmak anlamına da gelir. Sağlık sadece tıp biliminin konusu içine girmez. Tüm dünyada kabul edilen sağlık tanımı kapsamında bakıldığında, insanın bedensel sağlığı ile tıp hekimlerinin çalışma alanına girer. Ruhsal sağlığı ile ruh hekimleri ilgilenir. Sosyal sağlığı ile kimin 
ilgileneceği Türk mevzuatında tam olarak gösterilmemiştir. Ancak sosyal alanlarda araştırma yapanların ilgilenmesi gerekir kanaatindeyiz.

Sosyal bakımdan iyilik durumu, insanın karşısına çıkan sorunların altında kalmaması, ezilmemesi, onlarla baş edebilecek güce sahip olması demektir. Kişinin, sosyal sorunlar karşısında kendini güçsüz görmesi ve bu sorunları çözme becerisini yitirmesi sosyal bir hastalıktır. Yaşadığ1 sosyal çevre içindeki sorunlar karşısında çözücü tavır alamayan ve çaresiz kalan kişi de sosyal bakımdan sağlıklı değildir. Toplumla doğrudan yüzleşemeyen insan da sağlıklı değildir. Sağlıklı insan, toplumdan korkmayan ve onunla iletişime girebilen kişidir (Tomanbay, 2014: 86, 87).

Sosyal yönden iyilik hâlinin bilincinde olan sağlık Bakanlığı, Corona virüs salgınının ülkemizde görülmeye başlamasının ardından duruma yönelik Bilim Kurulu oluşturuldu. Sağlık Bakanlığ1 tarafindan oluşturulan ve bir araya getirilen kurul üyeleri, corona virüs mücadelesinde alınan kararlarda etkili olmaktadır. Bakanlık daha sonra da Koronavirüs salgınında sosyoloji, iletişim, psikoloji, din sosyolojisi, istatistik gibi alanlarda çalışacak "Toplum Bilimleri Kurulu”nu kurmuştur. Bu kurullar sağlığın sosyolojik boyutunun önemini gözler önüne sermektedir.

Bize göre de sağlıklı olmak için, sosyal iyilik hâlinin ve sosyal desteğin olması şarttır.

Sağlık alanında araştırma yapan araştırmacılar sosyal iyilik hâline bedensel ve ruhsal iyilik kadar ilgi göstermemiştir. Oysa sosyal iyilik hâli bedensel ve ruh sağlığıyla yakından alakalıdır. Ancak bu iyilik hâlinin net bir tanımı yapılmamıştır. Sosyal iyilik hâli ile ilişkili çok kavram vardır. Kavramların çokluğu anlamayı zorlaştırmaktadır. Sosyal iyilik, gelir dağılımı, eğitim, gibi sosyal değişkenlerden çok sosyal ilişkilerle alakalıdır. Sosyal iyilikle ilgili olarak yapılacak çalışmalar toplumun işleyişini ve düzenlenme şeklini hesaba katması gerekir. Ancak bu çalışmalar sonucunda sosyal iyi kavramsal bir temele dayandırılabilir ( Babaoğlu vd, 2009).

Sosyal iyilik hâli konusuna hekimlerin yeterli ilgiyi göstermemelerinin sebeplerinden biri de yapılan tıbbı müdahale sonucunda ceza görme endişesidir. Hekimlerin tıbbi müdahale sonucunda ceza görmemeleri için, bu müdahalenin, endikasyona (tıbbı zorunluluğa) dayalı olması, hastanın aydınlatılmış rızasının alınması ve tıp biliminin gereklerine uygun bir şekilde yapılmış olması gerekir. Tanınmış, bilinen, yerleşmiş yöntemler kullanılarak yapılan tıbbi müdahalelerde hekimin aydınlatma yükümlülügünün kapsamı daralmakta, yeni yöntemler tercih edildiğinde ise genişlemektedir. Müdahalenin aciliyeti veya hayati tehlike söz konusu olduğunda, aydınlanmanın kapsamı da daralmaktadır. Göze alının riskin büyüklüğü arttıkça, aydınlatma borcunun kapsamı genişlemektedir (Petek, 2013: 65, 118). Hekim hastanın rıza gösterdiğinden fazlasını yapamaz. Örneğin endikasyonun bulunmadığ1 hâllerdesırf hasta istiyor diye hekim sezaryen yapmamalıdır. Aksi durumda tıbbi müdahalenin, borçlar hukuku, ceza hukuku ve idare hukuku bakımından cezai sorumluluğu vardır. Be sebeple hekimler mecbur olmadıkça standart tıbbi uygulamanın dişına çıkmak istememektedirler. Hekimler tıbbi yanlış uygulama konusunda çok hassastırlar. Tibbi yanlış uygulama (malpractice), doktorun tedavi sırasında standart uygulamayı yapmaması, beceri eksikliği veya hastaya tedavi vermemesi şeklinde oluşabilmektedir.

Standart Tibbi Uygulamayı belirlerken hekimin her yeni yöntemi uygulamakla yükümlü olmadığını, hekimin yükümlülügünün yerleşmiş kuralları uygulamak olduğunu göz önünde bulundurmak gerekmektedir. Ancak Standart Tibbi Uygulamanın hekimin müdahaleyi yaptığ1 yerin koşulları uyarınca ulaşabilir olması gerekmektedir. Bu nedenle Standart Tıbbi Uygulama belirlenirken her somut olay ayrı ayrı değerlendirilmelidir.

\section{Koruyucu Hekimlik Olarak Neler Önerilebilir?}

Genel olarak ele alınırsa koruyucu hekimlik, hayat tarzının, beslenmenin, psikolojik durumun, stresin ve sporun üzerinde durmaktadır. SEBERYILDIZI, Nazlı Defne Seferyıldız'in "Koruyucu Hekimlik" makalesinde bilirttiği gibi(Seberyıldız1, 2006). "Koruyucu Hekimlik", Koruyucu hekimlikle ilgili hareketler ve davranışlar yürekten yapılmalıdır. İnsanlar davranışlarında şeffaf, açık ve stresten 
uzak bir gün geçirmesinin kültürünü edinmelidirler. İnsan toplumsal bir varlık olması nedeniyle, sosyal ilişkiler ağını da yapısına uygun olarak kurmalıdır. Ayrıca kendine mutlaka zaman ayırmalıdır.

$\mathrm{Bu}$ aşamalardan sonra koruyucu hekimlik görevini tedavi edici hekimliğe birakıyor. Önemli olan hastalığı tedavi edici aşamaya getirmemektir.

Sosyal iyilik durumu, toplum içinde uyumlu, yararlı ve üretici olma hâlidir. Yaşam, biçimi ekonomik durum ve toplumun kültürel özellikleri gibi etmenler kişinin sosyal durumunu etkiler (Özkan, s. 30).

İnsan tek başına bir ada değildir. İçinde bulunduğu toplumun önemli bir parçasıdır. Dolayısıyla kişinin sağlık durumunu anlayabilmek için, yaptığı işi, yaşadığ1 çevreyi, sosyo-ekonomik ve kültürel şartları da göz önünde tutmak gerekir. Bu faktörlerin hepsinin sağlık üzerinde tesiri vardır.

Birleşmiş Milletler Kalkınma Programı (UNDP), insanca gelişmeyi ölçebilmek için, beş farklı ölçüt kullanır. Bunlar ölçütler şunlardır:

İnsani Gelişme Endeksi

Toplumsal Cinsiyet Eşitsizliği Endeksi

Cinsiyete Dayalı Gelişme Endeksi

Eşitsizliğe Uyarlanmış İnsani Gelişme Endeksi

Çok Boyutlu Yoksulluk Endeksi

$\mathrm{Bu}$ ölçütler incelendiğinde, UNDP'nin insanca gelişmeyi ölçen en önemli karakteristikler olarak sağlık, eğitim ve gelirden yararlandığ anlaşılmaktadır. Bu Birleşmiş Milletlerin, yoksulluk tanımını oluşturan ögelerle de uyum gösterir.

Dünya Sağlık Örgütü (DSÖ) tarafindan benimsenen ve on başlık altında toplanan sağlığın sosyal belirleyicileri şunlardır:

İnsanların yaşamlarını sürdürmek için gereken bazı imkânlardan uzun süre uzak kalması (dezavantajlı olmasi)

Sosyal çevre ve psikolojik etkileri (stres)

Hayatın ilk yıllarında olumsuz çevre etkileri (anne ve çocuk sağlığı)

İşin sağlık üzerindeki etkisi

İssizilik ve iş güvenliğinin olmaması

Arkadaşlik ve sosyal uyum

Sosyal dişlanma

Alkol ve diğer bağımlılık yapıcı maddeler

Sağlıklı beslenme ve gida güvenliği

Sağlıklı ulaşım

Bu faktörlerin hepsi, sağlıkta sosyal desteğin önemini gözler önüne sermektedir. Kötü sosyal ve ekonomik şartların ömür boyunca sağlı̆̆1 olumsuz etkilediği, sosyo ekonomik düzey düştükçe hastalık oranlarının arttığı, ömür beklentisinin azaldığı ve ciddi sağlık sorunlarını da beraberinde getirdiği bir gerçektir.

Sosyal ve psikolojik şartların uzun süreli strese, endişeye, güvensizliğe, özgüven eksikliğine, sosyalizolasyona, kontrol bozukluğuna sebep olduğu, ruh sağlığının bozulmasına ve erken ölümlere yol açtı̆̆1, güvensizlik, arkadaş ve akraba desteğinin olmamasının sağlığı olumsuz olarak etkilediği sunmuş olduğumuz bilimsel araştırmalar ortaya koymaktadır.

Bütün araştırmaların birleştikleri nokta, kişinin sosyal ilişki alışkanlığının, onun daha az oranda hastalanmasına de daha uzun bir süre yaşamanıza yardımcı olacağıdır. Gerçekten Fark edilmek, 
hissedilmek ve önemsenmek, acıyı anlamlı ölçüde hafifletir. Endişe ve terslenmek ise güçlendirir "(Goleman, 2010: 312).

İnsan kendi iç dünyasını açacak kişilere ihtiyaç duyuyor. "Duygularınız hakkında konuşmak güçlü kanser ilacıyla aynı etkiyi sahip olabiliyor. Kanser hastasındaki bir tutam duygu bedenle bir ilacın molekülleri gibi iletişim kurabiliyor." (Chopra, 2010: 226).

\section{Sonuç ve Teklifler}

Bu çalışmada sosyal ilişkilerin sağlık üzerindeki etkileri tespit edilmeye çalışılmış ve zayıf sosyal ilişkilerin doğurduğu sorunlara dikkat çekilmiştir. Elde edilen temel bulgu, "Dünya Sağlık Örgütü" tanımında geçen "Sosyal Yönlerden İyilik Hali" ibaresinin mutluluğun ve sağlığın temel unsurlardan biri olduğudur. Araştırma sonuçları sağlığın sosyolojik bir boyutunun olduğunu gözler önüne sermektedir.

İnsanların birbirlerine karşı tepkileri, kalplerinden bağışıklık sistemine kadar her şeyi etkileyebiliyor. $\mathrm{Bu}$ tepkiler vücudun hormon salgılamasına sebep olabiliyor. Bu sebeple kişi sağlıklı olmak için midesindeki hastalığa verdiği önem kadar, çevresiyle barışı olmaya da özen göstermelidir.

Yapılan bu araştırmalar, bir bütün olarak değerlendirildiğinde, sosyal ilişkiler ile sağlık arasında anlamlı bir ilişskinin olduğunu göstermektedir. Ayrıca sosyal ilişkilerin bir kişide meydana getirdiği sağlık ve mutluluk, o kişinin etrafindakileri de olumlu yönde etkilemektedir.

Kişinin duygularını boşaltmak için, sağlıklı ilişkiler kurabileceği insanlara ihtiyacı vardır. Kaliteli sosyal ilişkiler, sağlığ1 olumlu yönde etkilemekte, bağışıllık sistemini güçlendirmekte ve stresi önlemektedir. Çünkü bu ilişkilerle insan sevildiğini, değer verildiğini, kabul gördügünü ve önemsendiğini hisseder.

\section{Teklifler}

Birey, mutlu ve sağlıklı olmak için, sağlıklı sosyal ilişkiler kurmak zorundadır. Mutlu olmak isteyen kimse arkadaşlarını ve çevresini hedeflerine göre seçmelidir. Hayat kalitesini yükseltmek için olup biteni ve sosyal ilişkilerin önemini iyi kavramalıdır.

İnsanlar günlük hayatlarının ve yakın çevrelerinin bir parçası olurlar. Etraflarındaki kişilerin etkileri altında kalırlar. Arkadaşlarından, ailesinden, birlikte çalıştıkları kişilerden etkilenmeyen insan bulmak çok zordur. Bu gerçeğin ışı̆̆ında kişiler insanlar arası iletişim becerilerini iyi yönetmelidirler.

İnsanlar mutluluklarını paylaşmalıdırlar. Paylaşılan mutluluk çoğalır. Charlotte Bronte' nin ifadesiyle, "Paylaşılmamış bir mutluluğa, mutluluk demek güçtür; hiçbir tadı yoktur."

Kişi tepkisel insanlarla beraber zaman geçirdiğinde, o da tepkisel olmayı öğrenir. Mutlu insanlarla beraber olur ise, mutluluğu öğrenir. Dağınık insanların yanında, dağınık olmayı öğrenir. Zengin insanların arasında, zengin olmayı öğrenir... Yoksul insanların yoksul arkadaşları vardır. Bu sebeple kişi öncelikle kiminle birlikte yaşayacağına iyi karar vermelidir.

Sosyal ilişkiler faydalı, yalnızlık ise ömür törpüsüdür. Yalnız yaşamak zararlıdır. Ailesine, arkadaşlarına ve topluma daha sosyal bir şekilde bağlı olan kişiler, çevresi daha sınırlı olanlardan daha mutlu, daha sağlıklı ve daha uzun yaşıyor. Bu sebeple kişi mümkün mertebe yalnızlıktan uzak durmalidir.

Ruh kendini ifade edemeyince hastalanır. Carl G. Jung'un ifadesiyle, "Nevroz (içsel çatışma) anlamını bulamamış ruhun acı çekmesidir." Ruh anlamını da ancak diğer insanlarla birlikte olduğu zaman bulabilir. Ken Keyes'in ifadesiyle "İfade edilmeyen duygular, beyinde hizla yayılan kanser gibidir. Algılarımızı çarpıtır, yabancılaştırır ve acı getirir. Bu sebeple, kişi kendini başkalarına sağlıklı bir şekilde açmalıdır. 
Kişi, hayatınıza anlam katmalı. Ruhun kendini ifade edemeyince hasta olacağını unutmamalı. Dünyada güzel bir iz bırakmalı. Hayatında hiç kimse üzerinde iz bırakmayan ölümden çok korktuğu unutulmamali.

İnsanların birbirine karşı tepkileri sağlı̆ıını etkiler. Sosyal ve ruhsal yönden iyi olmayanlar da hasta olarak kabul edilmeli.

Sağlıklı olmak isteyin kişi, ailesine ve dostlarına daha fazla zaman ayırmalı. Kavgayı alışkanlık hâline getirerek bağışıklık sisteminize zarar vermemeli.

Bir doktorun hastasına şu sözleri söylemesini bekler misiniz?

"Beyefendi hastalı̆̆ınızın teşhisi kondu, siz sosyal destek yetersizliği çekiyorsunuz. Bu hastalık kalp rahatsızlıklarına, bağışıklık ile ilgili hastalıklara ve de yüksek tansiyona yol açabilir. Bu yüzden size sosyal destek alabileceğiniz bazı aktiviteler vereceğim ve benim sizden isteğim bunlara hemen başlamanız.

$\mathrm{Bu}$ süreç içeresinde bu sosyal aktiviteler, tansiyonunuzun düşmesine ve kalp rahatsızlığınızın giderilmesine yol açacaktır. Hemen şimdi etrafınızdaki sevdiğiniz arkadaşlarınızdan, eşinizden, aile fertlerinizden, toplumsal kuruluşlardan ve sevdiğiniz diğer insanlardan destek alacaksınız. Onları daha çok sevecek ve onlarla iyi vakitler geçireceksiniz.

\section{Kaynaklar}

ANNE, Defaur, Laurance Wittner, L.( 2009). Okinawa Rejimi-Uzun Yaşam Rebberi, İstanbul: Dharma Yayınları.

ASLANTÜRK, Zeki-AMMAN, Tayfun (1999). Sosyoloji, İstanbul: İrfan Yayınevi.

BABAOĞLU, Melih; YAŞAR, Ümit; DOS, Turhan ve S. Oğuz KAYAALP (2009). "Kanita Dayalı Tip: Kavramlar, Örnekler ve Görüşler", Erişim Tarihi: 4.3.2020, https://www.turkiyeklinikleri.com/article/tr-kanita-dayali-tip-kavramlar-ornekler ve gorusler 56027.html

BARTENS, Werner (2009). Sağlık, çev. Itır Arda, İstanbul: NTV Yayınları

WARE, Bronnie(2012). Ölmeden Önce En Çok Pişman Olduğumuz Beş Şey, çev. Melihe Özge Onan, İstanbul: Yakamoz Yayınları. Yayınları.

COUSINS, Norman (2003). Hasta Gözüyle Hastahk, çev. Murat Sağlam. İstanbul: Dharma

DALAİ, Lama ve CUTLER, Howord(2000). Mutluluk Sanatı, çev. Güneş Tokcan, İstanbul: Klan Yayınları.

Goleman, Daniel, Sosyal Zeka, çev. Osman Çetin Deniztekin, İstanbul: Varlık/ Bilim,

DEEPAK, Chopra (1987). Sağğğ̊ Yaratma, çev. Mehmet Çatak, İstanbul: İnkilap Yayınları. Yayınları.

DENNIS, Prager (1998). Mutluluk. Ciddi Bir Sorundur, çev. Orhan Tuncay, İstanbul: Alkım

DOĞAN, Tayfun(2008). "Pozitif Psikoloji” Psikolojiye Giriş, (İstanbul: Pegem Akademi.

FIŞEK, Gürhan (2015). "Sosyal İyilik Hali", Erişim Tarihi; 4.3.2020, (https://Sosyalpolitika.Fisek.Org.Tr/Sosyal-İyilik-Hali/). Yayınları.

GLADWELL, Malcolm (2018). Çizginin Dışındakiler, çev. Aytül Özer, İstanbul: Medicat 
GOTTMAN John-Nan SILVER(2002). Evlilï̆i Sürdürmenin Yedi İlkesi, çev. Ezgi Deniz, İstanbul: Varlık/Özel Yayınları.

İLHAN, İnci Özgür. "Ruh Sağllğının Sosyal Boyutu", Erişim Tarihi:4.3.2020, "https://www.turkiyeklinikleri.com/article/en-sosyal-iyilik-hali-83291.html"

KLEİN, Stefan (2004). Mutluluğun Formülü, çev. Öğün Duman, Ankara: Arkadaş Yayınları. Yayınları.

LYUBOMIRSKY, Sonja (2008). Nasıl Mutlu Olunur, çev. Gülfer Göze, İstanbul: MediaCat Yayınları.

ÖZKAN, Zülfikar (2018). Sosyal İliskkilerin İyilestirici Gücü, İstanbul: Üsküdar Üniversitesi

ÖZKAN, Zülfikar (2017). Kendinle Barıșmak-Iç İletişimin İyileștirici Gücü: İstanbul: KOCAV Yayınları.

ÖZKAN, Zülfikar (2011). Sağhlkta İletişimin Gücü, İstanbul: Optimist Yayınları.

PETEK, Hasan (2013). Sağhle Hukuku, Eskişehir: Anadolu Üniversitesi Yayınları.

RADO, Şevket (1956). Eşref Saat, İstanbul: Doğan Kardeş Yayınları.

SEBERYILDIZI, Nazlı Defne (2006). "Koruyucu Hekimlik", Erişim Tarihi: 4.3.2020, (https://m.bianet.org/bianet/saglik/83605-yasam-tarzi-tibbi-koruyucu-hekimlik).

SERVAN-Schreiber (2008). Anti Kanser, çev. Filiz Nayır Deniztekin, İstanbul: Varlık Yayınları.

SEYITOĞLU, Halil (2003). Bilimsel Araștıra ve Yarma El Kitabı, İstanbul: Güzem Yayınları.

TARHAN, Nevzat (2019). Genç Arkadaşım, İstanbul: TIMAŞ Yayınları

TOMANBAY, İlhan (2014). Sosyal Olmak, İstanbul: SABEV Yayınları.

YILMAZTÜRK, Metin Y.(2008). Sağlıklı Yaşamak, İstanbul: Pagasus Yayınları. 